\title{
UM POUGO DA HISTÓRIA DA LUTA FEMINISTA PELA DESGRIMINALIZAÇÃO DO ABORTO NO BRASIL
}

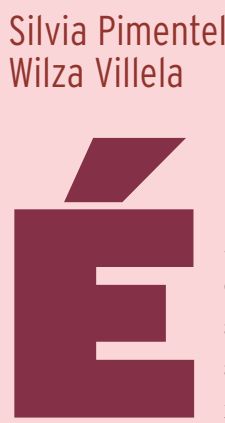

Silvia Pimentel

Wilza Villela

manos das mulheres.

Ao final daquela década, o discurso feminista dos direitos humanos das mulheres assumia, como premissa, o "nosso corpo nos pertence", o que diferenciava o movimento feminista do movimento de mulheres. Para as mulheres feministas, o direito ao aborto, a escolha de ter ou não ter filhos e o livre exercício da sexualidade eram, e ainda são, requisitos básicos e necessários de justiça social e para a consolidação das democracias.

A introdução da defesa da legalização do aborto na agenda política definiu fronteiras entre o movimento feminista e o movimento de mulheres, mais voltados para a garantia de acesso a equipamentos sociais que para a conquista de autonomia (1).

Nesse período, a disputa política com a hierarquia da Igreja Católica em relação ao aborto ganhou força, levando as feministas a definir uma estratégia que associava o aborto ao leque de reivindicaçóes mais gerais voltadas para a saúde integral das mulheres.

Concomitantemente, nasce no interior da Igreja um movimento impulsionado por mulheres cristãs propondo discutir o direito das mulheres de decidirem pelo aborto. No mundo sindical, a Comissão de Mulheres da Central Única dos Trabalhadores propõe incorporar na sua agenda a luta pela legalização do aborto, posicionamento que reverbera para outras centrais sindicais. Outros parceiros também se aproximam, como partidos políticos e associações profissionais, a exemplo da Federação Brasileira de Ginecologia e Obstetrícia (Febrasgo).

Ao abordar rapidamente essa história estamos enfatizando a importância política de revisitar, no século XXI, em 2012, a discussão sobre o direito ao aborto, no contexto do debate sobre a efetivação dos direitos humanos na sociedade brasileira.

O tema dos direitos humanos não é novo na agenda das mulheres. Há anos, mulheres como Emma Goldman, Flora Tristán, Nisia Floresta, Bertha Lutz, entre outras, já o discutiam. As feministas brasileiras, ex-exiladas, ex-presas políticas, no final da década de 1970 e no início da década seguinte, mais uma vez o colocaram em foco, situando a luta pelo direito ao aborto no centro desse debate.

Discutir o direito ao aborto desconstrói o paradigma hegemônico da maternidade compulsória. Quando o debate sobre a legalização ou descriminalização do aborto passou a envolver outros atores, essa desconstrução foi ressignificada, e a defesa do direito ao aborto passou a ser percebida também como um posicionamento solidário com as inúmeras mulheres que abortam na clandestinidade, em situação de ameaça à sua integridade física, psíquica e mesmo à sua vida $(2 ; 3)$.

Defender a descriminalização ou legalização do aborto é lutar por um projeto de sociedade equânime nas relaçōes de gênero, tendo a equidade como princípio e diretriz para que as diferenças possam ser convividas e vivenciadas dentro do mesmo espaço. Ao negar a subsunção das mulheres à maternidade, afirmando que elas podem ser mulheres na sua integralidade sem ter filhos e dissociando sexualidade e reprodução, constrói-se a ancoragem necessária para tratar do aborto no âmbito dos direitos humanos e dos direitos reprodutivos e sexuais.

O ABORTO NÃO É UM BEM EM SI MESMO Admitindo-se a dignidade humana e os direitos fundamentais da mulher, considerando-se que a vida do feto, em geral, deve ser protegida e reconhecendo que a educação na área da sexualidade e da reprodução é comprovadamente a única política pública que apresenta resultados satisfatórios na redução da incidência do aborto, conclui-se que qualquer legislação que vise a diminuir a realização de abortamentos, deve ser preventiva e não punitiva.

O debate atual sobre o aborto no Brasil apresenta-se eivado de equívocos e ambiguidades. A começar pela colocação da questão nos termos "ser contra ou a favor do aborto", que revela, de um lado, uma grande simplificação do problema e, de outro, má fé em relação ao tema, pois configura, falaciosamente, dois grupos em oposição, "os a favor da vida e os contra a vida".

Os defensores do direito ao aborto não são contra a vida, e o aborto, em si, não é um bem, mas o Estado não tem o direito de incriminar uma mulher que decide interromper uma gravidez que ela não pode suportar.

Tratar do direito ao aborto hoje significa ter como referência a justiça social e considerar os direitos de quem aborta e de quem exerce essa intervenção - mulheres e profissionais de saúde, a partir de quatro princípios éticos: o princípio da integridade corporal, que é o direito à segurança e o controle do próprio corpo, como um dos aspectos do conceito de liberdade reprodutiva e sexual; o princípio de igualdade, que inclui a igualdade de direitos entre mulheres e homens e entre todas as mulheres; o princípio da individualidade, que diz respeito à capacidade moral e legal das pessoas, implicando no direito à autodeterminação, o respeito à autonomia na tomada de decisões sexuais e reprodutivas e o princípio da diversidade, que se refere ao respeito pelas diferenças entre as mulheres (1). 
Enfim, falar do direito ao aborto implica resgatar a radicalidade do feminismo trinta anos depois (4), para que o discurso sobre a opressão das mulheres, que tem nas experiências vividas durante as situaçôes de aborto clandestino a sua maior expressão, não se torne desencarnado da própria concretude do sujeito mulher.

Silvia Pimentel é professora da Pontifícia Universidade Católica de São Paulo (PUC-SP), representante do Brasil no Committee on the Elimination of Discrimination Against Women (Cedaw), da $O N U$

Wilza Villela é médica psiquiatra, professora visitante do Departamento de Medicina Preventiva da Universidade Federal de São Paulo (Unifesp).

\section{REFERÊNCIAS BIBLIOGRÁFICAS}

1. Villela, W. Advocating for abortion access. Johanesburg: University of Witwatersrand; 2001.

2. Boemer, M.R., Mariutti, M.G. “Women facing abortion: an existential approach". Rev Esc Enferm USP. 2003;37(2):59-71.

3. Oliveira, M.E. "Aborto: desafios da legalidade". Recife: Cadernos SOS Corpo. Vol. 2; 1998.

4. Delphy, C. "Para redescobrir o feminismo". Le Monde Diplomatic Brasil. [magazine on line]. Maio de 2004 [acesso em 2 april 2011]. Disponível em: http://www.diplomatique.org.br/acervo. php?id=1158\&tipo=acervo.

\section{DIREITOS SEXUAIS E REPRODUTIVOS DAS MULHERES NO BRASIL: GONQUISTAS REGENTES E DESAFIOS PREMIENTES}

\author{
José Gomes Temporão
}

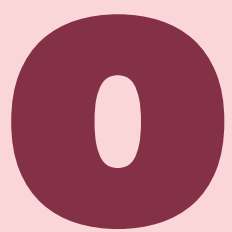

Programa de Assistência Integral à Saúde da Mulher foi criado em 1983 no contexto da redemocratização do país e na esteira da Conferência de Alma-Ata (1978), que definiu as bases da atenção primária em saúde. Os movimentos sociais e os movimentos de mulheres, principalmente o movimento feminista, influenciaram a construção do programa (1).

Paralelamente, no âmbito do Movimento Sanitário, se concebia o arcabouço conceitual que embasaria a formulação do SUS. A implementação do Programa nos anos 1990 foi influenciada pelas características dessa nova política de saúde e norteada pelos princípios da integralidade e da equidade da atenção.

Em 2004, o programa foi transformado na Política Nacional de Atenção Integral à Saúde da Mulher. O intuito da política é promover a melhoria das condiçóes de vida e saúde das mulheres por meio da: (i) garantia de direitos; e (ii) ampliação do acesso aos meios e serviços de promoção, prevenção, assistência e recuperação da saúde.

Este artigo vai apresentar os principais avanços na área dos direitos sexuais e direitos reprodutivos alcançados na última década e destacar que, apesar das conquistas de cidadania verificadas nesse período, a agenda pública nessa área necessita romper preconceitos arraigados em alguns setores da sociedade para que possamos vislumbrar, a curto prazo, melhores indicadores de morbimortalidade da mulher brasileira.

PLANEJAMENTO REPRODUTIVO NO ÂMBITO DA ATENÇÃO INTEGRAL A ampliação do acesso pelas mulheres aos métodos contraceptivos representa indicador importante para avaliar a atenção à saúde da mulher. Em 2006, 99\% das mulheres que participaram da Pesquisa Nacional sobre Demografia e Saúde (PNDS)(2) afirmaram conhecer ou ter ouvido falar de algum método contraceptivo. A prevalência de uso de métodos chega a alcançar $55 \%$ já nas primeiras idades (15-19 anos). Mais de 90\% das mulheres unidas em todas as idades já praticaram algum tipo de anticoncepção, especialmente pelo uso de métodos modernos de alta eficácia (pílula, injetáveis, preservativo, entre outros). Em relação ao uso de preservativos, a Pesquisa Nacional de Comportamentos e Atitudes (3) (PCAP), de 2008, revelaram que $57,6 \%$ das mulheres em idade fértil afirmaram ter utilizado o preservativo na primeira relação sexual. Em 2004, esse número era de $54,3 \%$.

O número de atendimentos clínicos (4) para indicação e fornecimento de diafragma e indicação de procedimento e inserção de dispositivo intrauterino no período de 2003 a 2008 indica, igual- 